\title{
PENYELESAIAN KONFLIK PERTANAHAN PADA KAWASAN PARIWISATA LOMBOK (STUDI KASUS TANAH TERLANTAR DI GILI TRAWANGAN LOMBOK)*
}

\author{
Zainal Asikin \\ Fakultas Hukum Universitas Mataram \\ Email: asikinzainal@yahoo.com
}

\begin{abstract}
This research is aimed at exploring an appropriate solution for various conflicts in land use, particularly in optimizing the utilization of the neglected land in Gili Terawangan, Lombok Island. This solution is required to avoid potential horizontal conflicts among people, companies and government since 1993. Conflict over land in Lombok Island in general and Gili Terawangan particularly shows several factors; first, the wrong policy in the area of land (especially in tourist areas); second, the infirm attitude of the Party and the Government Land Office in the enforcement of laws; third, the jealousy of Gili Terawangan natives as cultivators; fourth, less responsibility employers (who acquire cultivating right); fifth, the absence of law protection for Gili Terawangan natives; sixth, the arrogant attitude of law enforcement officers. The comprehensive and final resolution to the conflicts of land use could only be achieved if: (i) the people, who already control and use or manage the land from time to time, are provided certainty on managing and optimizing the land based on the principles of welfare, justice, equity, efficiency and sustainability; (ii) the selection and determination of the companies that will be granted the right to cultivate (HGU) and the right to build (HGB) should be conducted based on the transparent principle. In this respect, the government could establish an independent team that involves all components of society and higher education.
\end{abstract}

Key words: land dispute, tourism area, agrarian law.

\begin{abstract}
Abstrak
Penelitian ini mengkaji konflik pertanahan yang terjadi di Pulau Lombok khususnya pada tanah terlantar di Daerah Wisata Gili Trawangan yang tidak pernah terselesaikan sejak tahun1993 sampai saat ini. Konflik pertanahan di Gili Terawangan disebabkan oleh beberapa faktor. Pertama, adanya kebijakan yang salah di bidang pertanahan (khususnya di kawasan wisata); kedua, adanya sikap yang tidak tegas dari Pihak Pemerintah Daerah dan Badan Pertanahan dalam penegakan peraturan hukum pertanahan; ketigaa, danya kecemburuan sosial dari masyarakat asli Gili Terawangan sebagai penggarap; keempat pihak pengusaha kurang adanya tanggungjawab pengusaha (yang memperoleh Hak Guna Usaha); kelima, tidak adanya perindungan hukum bagi Penduduk Asli Gili Terawangan; keenam, sikap arogansi aparat penegak hukum. Penyelesain konfik pertanahan hanya dapat dilakukan secara tuntas dan menyeluruh, pertama apabila masyarakat yang telah bertahun tahun menempati lokasi tanah tersebut diberikan kepastian hak untuk mengelola lahan tersebut sehingga memenuhi prinsip kesejahteraan(wefare), keadilan (equity), pemanfaatan secara optimal (efficiency) dan keberlanjutan (sustainability). Kedua pemilihan badan usaha yang akandiberikan HGU maupun HGB oleh Pemerintah pada tanah tanah pariwisata harus dilakukan secara selektif dan transparan oleh suatu tim yang independen yang melibatkan seluruh komponen masyarakat dan perguruan tinggi.
\end{abstract}

Kata kunci: konflik pertanahan, kawasan pariwisata, hukum agraria

Pendahuluan

Hampir di semua negara di belahan bumi ini terjadi konflik pertanahan, karena tanah

Artikel ini merupakan artikel hasil penelitian yang dilaksanakan berdasarkan kontrak pelaksanaan penelitian No. 654H/SP-BLU/UN18.12.2/PL/2013. merupakan kebutuhan yang mendasar bagikehidupan manusia. ${ }^{1}$ Propinsi Nusa Tenggara Barat merupakan salah satu propinsi di Indonesia

Agung Widodo, “Urgensitas Penyuluhan Hukum Agraria, Pada Masyarakat Rawan Konflik Pertanahan", Jurnal Yustitia, No.75 Th 2008, hlm. 2. 
yang memiliki potensi alamyangindahdengan sumber daya alamnyayang melimpah. Salah satu sektor yang dikembangkan adalah sektor kepariwisataan dengan harapan agar dapat meningkatkan kesejahteraan rakyat.

Cita-cita meningkatkan kesejahteraan rakyat melalui pariwisata itu dengan tegas telah diamanatkan dalam Padal 4 Undang-Undang No. 10 Tahun 2009 tentang Kepariwisataan menyebutkan bahwa kepariwisataan bertujuan untuk meningkatkan pertumbuhan ekonomi, meningkatkan kesejahteraan rakyat, menghapus kemiskinan, mengatasi pengangguran, melestarikan alam, lingkungan dan sumberdaya, memajukan kebudayaan, mengangkat citra bangsa, memupuk rasa cinta tanah air, memperkukuh jati diri dan kesatuan bangsa dan mempererat persahabatan antar bangsa.

Gili Trawangan di Pulau Lombok adalah salah satu gugusan kepulauan yang berada di sebelah Utara Pulau Lombok yang saat ini menjadi salah satu tujuan wisata dari wisatawan mencanegara. Gili Trawangan yang luas-nya sekitar 328 hektar dengan penduduk 800 jiwa adalah salah satu Gili di samping Gili Meno dan Gili Air yang menjadi incaran pemodal (investor) untuk dapat berinvestasi dalam bidang bisnis pariwisata.

Pesatnya perkembangan pariwisata memunculkan persoalan baru di bidang pertanahan. Klaim kepemilikan tanah menjadi persoalan yang semakin menonjol sehingga menimbulkan konflik pertanahan antara pemerintah (sebagai regulator dan pihak yang mengeluarkan izin), pemodal (investor) dan masyarakat asli Gili Trawangan (sebagai pembuka lahan perkebunan). Banyak kasus yang masuk ke pengadilan, namun diselesaikan dengan hasil yang kurang memuaskan. Berkembang pandangan di masyarakat bahwa badan peradilan tidak optimal dalam menyelesaikan sengketa pertanahan. Rasa keadilan dan kepastian hukum yang diharapkan masyarakat tersebut tidak terpenuhi, bahkan yang ada hanyalah persoalan baru yang dampaknya justru memperburuk kondisi yang ada. ${ }^{2}$ Hal ini melahirkan pola penyelesaian sengketa tanah yang didominasi oleh pola penyelesaian nonlitigasi, misalnya perdamaian melalui negosiasi, musyawarah mufakat, dan mediasi. ${ }^{3}$

Negara (pemerintah) memiliki hak mengeluarkan izin usaha pengelolaan bisnis pariwisata dan hak pengelolaan terhadap lahan sebagaimana diatur dalam Pasal 1 angka 3 Peraturan Menteri Negara/Kepala Badan Pertahanan Nasional No. 9 Tahun 1999 tentang Tata Cara Pemberian dan Pembatalan Hak atas Tanah Negara dan Pengelolaan. Negara dapat memberi dan mencabut hak pengelolaan atas tanah itu dan memberikannya kepada siapa yang dihendaki sesuai dengan mekanisme yang berlaku. Akan tetapi persoalan hukum dan konflik pertanahan muncul ketika pemerintah tidak mampu menjadi pihak yang netral dalam menyelesaikan persoalan pertanahan dan terjadinya salah tafsir terhadap hak menguasai Negara. Ketika konflik pertanahan muncul antara pemilik modal dengan rakyat, maka ada kecenderungan Pemerintah memposisikan diri sebagai pihak yang lebih membela kepentingan pemodal atau investor daripada memberikan perlindungan kepada masyarakat yang telah menguasai tanah tersebut berpuluh-puluh tahun sebagai petani.

Konflik Pertanahan di berbagai daerah disebabkan oleh beberapa faktor yaitu tindakan pemerintah (badan pertanahan) yang le-mah dalam melakukan penelitian dan mengidentifikasikan tanah terlantar. ${ }^{4}$ Tanah merupakan sumber kehidupan manusia karena tanah memiliki nilai ekonomis, nilai sosial dan nilai budaya. Sehingga lahirnya unifikasi hukum di bidang pertanahan yaitu Undang-Undang Pokok Agraria

2 R.Fitriani, "Penyelesaian Sengketa Lahan Hutan Melalui Proses Mediasi di Kabupaten Siak", Jurnal Unsri, No. 3 Vol.14 Juli 2007, hlm. 2.

3 Muhamad Galang Asmara dkk, "Penyelesaian Konflik Pertanahan Berbasis Nilai Nilai Kearifan Lokal di Nusa Tenggara Barat", Jurnal Mimbar Hukum, Vol. 22 No. 1 (2010), Yogyakarta: FH UGM, hlm. 1

4 Dara Hapsari Hastiti, "Penyelesaian Konflik Pertanahan di Kabupaten Nunukan di Kalimantan Timur antara Masyarakat dengan Perusahaan Perkebunan dihubungan dengan Peraturan Pemerintah No 11 Tahun 2010 tentang Penerbitan dan Pendayagunaan Tanah Terlantar", Jurnal Bina Mulia, Vol. 17 Oktober 2013, Bandung: FH UNPAD, hlm. 2. 
No. 5 Tahun 1960 dihajatkan menjadi alat regulator yang baik.

Hak milik atas tanah adalah hak yang terkuat bagi masyarakat, sehingga dengan mengalihkan fungsinya yang tidak semata mata dilihat sebagai nilai ekonomi, nilai sosial, maka hak atas tanah harus juga sebagai bermakna dalam pembangunan bangsa. Oleh sebab itu, pemberian perlindungan hukum di bidang hak milik atas tanah dalam praktek selain ditentukan oleh substansi hukumnya, juga ditentukan oleh aparat pelaksana dan kesadaran hukum masyarakat. Substansi hukum berupa peraturan perundang-undangan haruslah sesuai dengan cita-cita keadilan masyarakat dan perkembangan zaman. Keberadaan tanah adalah hal yang sangat vital bagi kehidupan, sehingga harus mendapat suatu perhatian yang khusus, tanpa adanya sebidang tanah maka manusia tidak dapat beraktivitas di dalamnya. Sebidang tanah memiliki nilai jual yang sangat tinggi dan mengalami peningkatan dari tahun ke tahun, seharusnya dengan kondisi seperti ini maka Pemerintah harus bisa menangani setiap ada permasalahan. ${ }^{5}$

Pemerintah harus mampu menempatkan diri sebagai pengayom dan melakukan keberpihakan kepada rakyat demi terciptanya rasa aman bagi rakyat. ${ }^{6}$ Perlindungan hukum terhadap hak-hak rakyat atas tanah dalam pembangunan adalah untuk memberikan perlindungan hukum bagi pemegang hak atas tanah terhadap tanahnya, maka dalam surat pernyataan pelepasan atau penyerahan hak atas tanah yang di buat oleh pemegang hak atas tanah perlu di buat klausula yang menyatakan bahwa apabila dikemudian hari diketahui ternyata pengadaan tanahnya bukan untuk kepentingan umum melainkan untuk kepentingan perusahaan dan lainlain, maka pengadaan tanah tersebut dianggap batal dan uang ganti rugi yang telah diterima

\footnotetext{
5 Siti Nurjannah, “Kajian Hukum Sengketa Pertanahan dan Penyelesaiannya (Putusan Kasasi MA No. 2863/K/ Pdt/1999 Dalam Perkara Perdata Tingkat Kasasi Antara PT. Portanigra Melawan H. Juhri M. Yatim Tugono dan Yahya bin H. Geni", Jurnal Supremasi Hukum, 2013, FH Universitas Sahid Jaya, hlm. 2.

6 Anis Ibrahim, "Penyelesaian Sengketa Tanah Kawasan Hutan Negara DI Kabupaten Lumajang", Jurnal Hukum Argumentum, Vol. 3 No.2 Januari-Juni 2004,hlm. 3.
}

akan dikembalikan kepada pani-tia pengadaan tanah atau pemegang hak. ${ }^{7}$

Konflik pertanahan di Gili Terawangan menjadi semakin tajam ketika pemerintah daerah mengambil alih tanah perkebunan dari tangan warga masyarakat yang menguasai lahan dengan membuka lahan (ketika masih semak belukar) dan pemerintah mengeluarkan himbauan kepada para Notaris/PPAT untuk tidak membantu warga yang ingin membuat sertifikat atas tanahnya. Pemerintah Daerah di sisi lain dengan begitu mudahnya memberikan izin usaha membangun hotel dan lain-lain pada lokasi yang dikuasai dan ditempati masyarakat kepada perusahaan tertentu tanpa memperhatikan eksistensi masyarakat setempat, baik masyarakat yang telah memiliki sertifikat hak milik atas tanah maupun masyarakat yang belum memiliki sertifikat. Pemberian surat-surat dan bukti-bukti formal kepada pengusaha di atas tanah yang digarap masyarakat dalam dimensi prulalisme hukum akan melemahkan posisi masyarakat. $^{8}$

Posisi pemerintah memang diberikan kewenangan untukmelakukan tindakan tindakan yang bertujuan untuk mempercepat proses pembangunan pariwisata di satu daerah. Akan tetapi acapkali pemerintah daerah luput memahamidan mengkaji norma hukum, serta pemerintah kurang memahami persoalan yang mendasarpada masyarakatyang menguasailahan.

Undang-Undang Dasar 1945 mengatur tentang perlindungan hak asasi manusia sebagai berikut. Pasal 28A menentukan bahwa setiap orang berhak untuk hidup serta berhak untuk mempertahankan hidup dan kehidupannya. Pasal 28D ayat (1) menentukan bahwa setiap orang berhak atas pengakuan, jaminan, perlindungan dan kepastian hukum yang adil serta perlakuan yang sama dihadapan hukum. Pasal 28 I (4) mengatur bahwa perlindungan, pemajuan, penegakan dan pemenuhan hak asasi manu-

\footnotetext{
Akh Munif, "Perlindungan Hukum Terhadap Hak-Hak Rakyat Atas Tanah Dalam Pembangunan (Kajian Atas Perpres No. 65 Tahun 2006)", Jurnal Justisia,Vol. 11 No.1 Mei 2011, Madura: FH Universitas Madura, hlm. 4.

8 Shidarta, "Peragaan Pola Penalaran Hukum Dalam Kajian Putusan Kasus Tanah Adat Kajian Putusan Nomor 22/ PDT.G/2004/PN. AB”, Jurnal Yudisial Pergulatan Nalar \& Nurani, Vol. III No. 03 Desember/2010, hlm. 207.
} 
sia adalah tanggung jawab negara, terutama pemerintah. Berkaitan dengan hal itu, dalam UU No. 10 Tahun 2009 tentang Kepariwisataan diatur tugas dan tanggung jawab negara dalam perlindungan hak asasi manusia itu dalam kerangka pembangunan sektor pariwisata sebagaimana diatur dalam Pasal 5 sebagai berikut :

a. Menjunjung tinggi norma agama dan nilai budaya sebagai pengejawantahan dan konsep hidup dalam keseimbangan hubungan antara manusia dan sesama manusia, dan hubungan antara manusia dan lingkungan ;

b. Menjunjung tinggi hak asasi manusia, keragaman budaya, dan kearifan lokal;

c. Memberi manfaat untuk kesejahteraan rakyat, keadilan, kesataraan dan proporsionalitas;

d. Memelihara kelestarian alam dan lingkungan hidup;

e. Memberdayakan masyarakat setempat;

f. Menjamin keterpaduan antar sektor, antar daerah, antar pusat dan daerah yang merupakan satu kesatuan sistematik dalam kerangka otonomi daerah, serta keterpaduan antar pemangku kepentingan;

g. Mematuhi kode etik kepariwisataan dunia dan kesepakatan internasional dalam bidang pariwisata; dan

h. Memperkukuh keutuhan Negara Kesatuan Republik Indonesia.

\section{Permasalahan}

Memperhatikan kaidah hukum di atas, sejatinya tidak akan terjadi konflik pertanahan pada kawasan pariwisata di Indonesia, termasuk di Kawasan Gili Terawangan karena hukum memberikan jaminan terhadap hak asasi manusia, memberdayakan masyarakat setempat, keadilan, kesejahteraan dan proporsionalitas. Kenyataan yang ada justrukonflik pertanahan di kawasan pariwisata Gili Terawangan Lombok sampai saat ini masih terjadi dan tidak tahu sampai kapan dapat terselesaikan. Hal ini menjadi perlu untuk dilakukan penelitian dan kajian tentang berbagai persoalan hukum. Permasalahan yang dibahas pada artikel ini ada dua. Pertama, apa yang menyebabkan terjadinya konflik pertanahan di kawasan wisata Gili Terawangan; kedua, bagaimana penyelesaian konfik terhadap pertanahan di Kawasan wisata Gii Terawangan.

\section{Metode Penelitian}

Penelitian ini merupakan penelitian normatif yaitu jenis penelitian yang terkait dengan pengkajian asas-asas hukum terutama yang menyangkut perlindungan hukum masyarakat terhadap hak atas tanah. Ada beberapa peraturan yang akan menjadi fokus kajianya itu UUD Tahun 1945, Undang-Undang No.5 Tahun 1960 tentang Undang-Undang Pokok Agraria, UndangUndang No. 10 Tahun 2009 tentang Kepariwisataan, Undang-Undang No. 32 Tahun 2004 tentang Pemerintahan Daerah, Peraturan Pemerintah No. 40 Tahun 1996 tentang Hak Guna Usaha, Hak Guna Bangunan dan Hak Pakai Atas Tanah, Peratuan Pemerintah No. 11 Tahun 2010 tentang Penertiban dan Pendayagunaan Tanah Terlantar, Peraturan Menteri Agraria/Kepala BPN No.9 Tahun 1999 tentang Tatacara Pemberian dan Pembatalan Hak Atas Tanah Negara dan Hak Pengelolaan, dan Peraturan Menteri Agraria/Kepala BPN No. 4 Tahun 2010 tentang Tatacara PenertibanTanah Terlantar. Pendekatan yang dilakukan dalam penelitian ini adalah pendekatan kasus (cases approach) yaitu dengan menganalisis kasus yang terjadi antara masyarakat Gili Terawangan dengan PT. Gili Trawangan Indah (PT. GTI) dan PT. Wanawisata Alam Hayati (PT. WAH).

Bahan hukum yang dibutuhkan dari pendekatan ini adalah bahan hukum primer yaitu peraturan perundangan yang terkait dengan Hak Guna Usaha serta dokumen yang diperoleh dari berbagi sumber yang terkait dengan tanah di Gili Trawangan. Analisa data yang dipergunakan adalah analisa kualitatis dengan melakukan deskripsi atas bahan hukum yang telah terkumpul, melalui sistematisasi bahan, melakukan konstruksi dan konklusi seluruh temuan bahan hukum

\section{Pembahasan}

Penyebab Terjadinya Konflik Pertanahan di Gili Terawangan

Tahun 1980 adalah awal terjadinya kebangkitan pariwisata di Nusa Tenggara Barat, 
khususnya di Pulau Lombok. Geliat kepariwisataan NTB tercermin dari angka kunjungan wisata ke NTB sebanyak 1.021 .179 orang, terdiri dari 489.405 wisatawan nusantara dan 531.774 wisatawan mancanegara (Data BPPS Tahun 2011). Dalam perspektif pembangunan ekonomi nasional yang tertuang dalam master plan Percepatan dan Perluasan Pembangunan Ekonomi Indonesia 2011-2015, Bali danNTB dijadikan sebagai pintu gerbang pariwisata dan pendukung pangan nasional, sehingga perhatian pemerintah pusat terhadap pembangunan pariwisata di NTB sangat besar hal itu dibuktikan dengan dibangunnya Bandara Internasional Lombok (BIL) yang diresmikan penggunaannya pada 2011.

Salah satu tujuan wisata di Pulau Lombok yang diminati oleh wisatawan mancanegara adalah Gili Terawangan, Gili Meno dan Gili Air yaitu suatu gugusan pulau yang terletak di Kabupaten Lombok Utara. Panorama alamnya yang sangat indah tidak mengherankan para investor mengincar 3 kawasan gili untuk membangun perhotelandan infrastruktur pariwisata lainnya yang sampai saat ini jumlah hotel melati di lokasi tersebut berjumlah 150 buah, 130 restoran, 11 Biro Jasa Travel 18 perusahaan jasa diving, dan 10 buah SPA/Salon.

Pemanfaatan tanah yang sebelumnya adalah tanah perkebunan, kemudian beralih menjadi tanah lokasi pariwisata dalam skala besar telah memicu terjadinya konfik pertanahan di Gili Trawangan. Konflik pertanahan tersebut terjadi karena peruntukan tanah yang semula dihajatkan untuk mempercepat proses kesejahteraan rakyat melalui pengembangan pariwisata di daerah, ternyata dalam praktik telah disalah gunakan menjadi barang komoditi yang diperjual belikan oleh para investor yang bertindak sebagai spekulan tanah. Artinya tanah tanah rakyat yang pada era Orde Baru diperoleh oleh investor yang dekat dengan penguasa dan dengan kekuatan ekonomi menggusur rakyat dengan dalih demi pembangunan, ternyata tidak dimanfaatkan sesuai dengan peruntukannya. Sebagai sebuah komoditi maka siapa saja yang memiliki kekuatan ekonomi boleh memiliki tanah, membeli tanah dan menjualnya kembali demi mencari keuntungan sesaat sehingga menciptakan suatu pola baru penguasaan tanah secara monopoli yang bertentangan dengan hakikat Undang-Undang Pokok Agraria (UUPA) yaitu mewujudkan suatu kesejahteraan bersama yang berkeadilan.

Hakikat politik agraria yang sosialis dan nasionalis itu tergambar dari pidato $M$. Hattadi Yogyakarta pada Tahun 1946, yang berisi beberapa hal. Pertama, tanah tidak boleh menjadi alat kekuasaan orang perorang untuk menindas dan memeras hidup orang banyak; kedua, tanah yang dipakai kebun kebun besar itu pada dasarnya adalah tanah tanah milik masyarakat; ketiga, tanah tidak boleh menjadi obyek perniagaan yang diperjual belikan semata mata untuk mencari keuntungan;keempat, seharusnya tidak terjadi pertentangan antara masyarakat dan negara karena negara itu alat masyarakatuntuk menyempurnakan keselamatan umum. ${ }^{9}$ Semangat yang disampaikan oleh $M$. Hatta itu telah diakomodir di dalam UUPA Pasal 13 ayat (2) dan (3) serta Pasal 26 ayat (1).

Pemerintahharus mencegah adanya usaha usaha di bidang agrarian dari organisasi dan perorangan yang bersifat "monopoli", dan jika ada usaha (badan usaha)yang menyelenggarakan usaha yang bersifat monopoli harus diselenggarakan dengan undang-undang. Jual-beli, tukar-menukar, penghibahan, wasiat dan pemberian selanjutnya menurut adat harus diatur dengan Peraturan Pemerintah. Jelas bahwa hukum agraria melarang adanya transaksi tanah yang bersifat spekulatif akibat memperlakukan tanah sebagai barang komoditi.

Studi terhadap konflik pertanahan di Pulau Lombok umumnya dan di Gili Terawangan khususnya ternyata memperlihatkan beberapa faktor. Pertama, adanya kebijakan yang salah di bidang pertanahan (khususnya di kawasan wisata); kedua, adanya sikap yang tidak tegas dari Pihak Pemerintah Daerah dan Badan Pertanahan dalam penegakan peraturan hukum pertanahan; ketiga, adanya kecemburuan sosial dari masyarakat asli Gili terawangan sebagai penggarap; keempat, pihak pengusaha kurang

9 Gunawan Wiradi, “Jangan Perlakukan Tanah sebagai Barang komoditi", Jurnal Analisa Sosial, Edisi 3 Juli 1996, Bandung: Yayasan Akatiga, hlm. 36. 
adanya tanggungjawab pengusaha (yang memperoleh Hak Guna Usaha); kelima, tidak adanya perindungan hukum bagi Penduduk Asli Gili Terawangan; keenam, sikap arogan aparat penegak hukum dengan melakukan penindakan semena-mena dan merobohkan bangunan Villa milik masyarakat yangtelah lama menghuni Gili Trawangan.

Berkaitan dengan faktor pertama, dapat dijelaskan sebagai berikut. Kekeliruan policy (kebijakan) pertanahan pariwisata di Pulau Lombok dan di Gili Terawangan bersumber dari pemberian Hak Guna Usaha kepada segelintir pejabat dan anak anak pejabat yang bukan pengusaha (Asep Kusuma (25 Ha), Kurnia Chandra Kusuma $(25 \mathrm{Ha})$, dan Kundang Kiswara (putra dan keluarga Gubernur NTB H. Wasita Kusuma seluas $25 \mathrm{HA}$ ) dengan perusahaan bernama PT Generasi Jaya, dan Sudarli, BA (Sekda NTB) seluas $25 \mathrm{HA}$. Pemberian Hak Guna Usaha itu menjadi awal dari terjadinya penelantaran tanah dan lahirnya transaksi spekuatif atas tanah pariwisata. Hal ini terjadi karena pihak yang memperoleh HGU bukan pengusaha maka tentunya tanah tanah lokasi pariwisata tidak mampu dikelola secara efektif dan produktif seperti yang dihajatkan dalam hukum agraria.

Penjelasan yang dapat diberikan berkaitan dengan faktorkedua adalah bahwa Pihak Pemerintah Daerah dan Badan Pertanahan sebagai institusi yang memberikan izin prinsip penggunaan kawasan pariwisata dan kemudian ditindak lanjuti dengan pemberian Sertifikat HGU oleh Badan Pertanahan Nasional kepada Pengusaha tertentu. Tindakan hukum dalam penyelesaian tanah Gili Terawangan yang ditelantarkan dalam praktiknya kurang tegas. Pemerintah daerah justru mengabaikan cita cita hukum agraria dengan mengambil begitu saja tanah yang sedang dikuasai dan digarap oleh mayasarakat berpuluh puluh tahun dan diserahkan kepada sekelompok orang dengan alas hak yang bernama Hak Guna Usaha (HGU) dengan Surat Keputusan Menteri Dalam Negeri tanggal 2 Nopember 1979 No. 26/HGU/DA/1979 jo No. 27/ HGU/DA/1979 jo No. 28/HGU/DA/1979 dan No. 26/HGU/DA/1979. Pemerintah terlalu berpegang pada bukti otentik bahwa para pemegang bukti hak harus dilindung, hal ini sejalan dengan keadaani pluralisme hukum yang lemah akan memberi keuntungan pada pihak-pihak yang mampu menampilkan bukti-bukti formal semata menurut perspektif hukum negara, sementara secara sosiologis para pemegang bukti formal itu telah mengabaikan kewajibannya dan merugikan Negara. ${ }^{10}$

Muncul dan semakin tajamnya konflik ketika Pemerintah Daerah Lombok Barat dan Badan Pertanahan Propinsi NTB memberikan perubahan status dari Hak Guna Usaha (HGU) menjadi Hak Guna Bangunan (HGB) kepada PT. Wanawisata Hayati (PT.WAH) di atas tanah HGU yang dulu pernah diberikan kepada Sudarli BA seluas 25 HA. Namun, di atas tanah tersebut telah dikuasai dan digarap oleh masyarakat sehingga pemberian HGB di atas kertas tercantum atas nama PT WAH seluas13,9 Ha dengan Surat Keputusan Badan Pertanahan Tanggal 14 Juni 1996 No. 550.2/05/I/43/621996 yang berlaku selama 30 tahun sejak tanggal 19 Juni $1996 \mathrm{~s} / \mathrm{d}$ 19Juni 2026 (Pemberian HGB oleh Badan Pertanahan Propinsi di atas tidak lepas dari adanya rekomendasi izin prinsip membangun yang diberikan Bupati Lombok Barat dengan No. 593/ 13/3tanggal 23 Maret 1996 dan Surat Pemberian Izin Lokasi Pembangunan Hotel oleh Badan Pertanahan Lombok Barat No.16/403/SK-IL/LB. 7/1996 tanggal 24 April 1996).

Butir 7 dalam Surat Keputusan Badan Pertanahan disebutkan bahwa dalam waktu 1 (satu) tahun sejak didaftarkanhaknya maka PT. WAH harus sudah memulai aktifitas pembangunannya. Apabila terjadi pelanggaran maka pemberian HGB ini batal dengan sendirinya (batal demi hukum). Dokumen Kebijakan Pertanahan Dalam Menunjang Investasi Khususnya Sektor Pariwisata di Propinsi NTB yang dikeluarkan oleh Kantor Wilayah Pertanahan Nasional NTB Juni 2003, terungkap bahwa PT. WAH telah menelantarkan tanahnya dan tanah yang diperoleh dengan HGB tersebut telah di duduki oleh masyarakat karena sejak tahun 1996 tanah tersebut belum pernah dikelola oleh PT. WAH sesuai dengan rencanasetelah memperoleh HGB.

10 Shidarta, loc.cit., hlm. 207. 
Tidak tegasnya pemerintah dalam mencabut izin dan HGU yang dipegang oleh pengusaha membuat mereka merasa dilindungi dan dibela meskipun telah melakukan kesalahan.

Penjelasan dari faktor ketiga adalah adanya kecemburuan sosial itu mencuat karena pemberian HGU itu penuh nuansa kolusi dan nepotisme yang hanya diperuntukkan bagi keluarga gubernur dan pejabat pemerintah serta pengusaha tertentu yang oleh masyarakat dianggap sebagai pengabaian hak hak masyarakat. Pemberian HGU itu dianggap oleh masyarakat sebagai sebuah rekayasa yang spekulatif karena tidak mungkin mereka yang memperoleh HGU (PT. Generasi Jaya) itu akan mampu mengembangkan Gili Trawanangan sebagai daerah kunjungan wisata mengingat orang-orang tersebut tidak berkecimpung dalam bisnis pariwisata dan bahkan seorang pegawai negeri yang dilarang berkecimpung dalam dunia bisnis. Dugaan masyarakat itu terbukti, sejak dikeluarkannya HGU kepada pihak-pihak tersebut ternyata pemegang HGU tidak pernah melakukan upaya pengelolaan atas HGU yang diberikan kepadanya. Bahkan, tanah yang berstatus HGU tersebut telah diperjual belikan oleh pemegang HGU (PT. Generasi Jaya) kepada orang lain bernama $\mathrm{H}$. Hasan Basri dengan perusahaan CV. Hikmah (Akta Notaris No. 54 Tanggal 17 Juli Tahun 1976) dan oleh H. Hasan Basri (CV. Hikmah) tanah tersebut dijual kembali kepada Agus Hadi Sunarto alias Ang Han Sin (PT.Gili Terawangan Indah) dengan Akta Notaris No.15 Tanggal 15 Agustus 1988. Jelas terbukti bahwa pemberian HGU pada kawasan pariwisata di Gili Terawangan Lomboktidak lebih dari adanya upaya yang bersifat spekulatif dan bernuansa kolusi yang menjadikan tanah sebagai komoditas yang diperjualbelikan bukan untuk melaksanakan cita-cita hukum agraria yang bertujuan mencapai kesejahteraandan kemak-muran rakyat.

Faktor keempat, yaitu kurang bertanggungjawabnya para pemegang HGU tersebut dalam melaksanakan kewajiban kewajibannya untuk mengelola tanah tersebut bahkan memperalihkan HGU itu pada orang lain. Pemerintah Propinsi mengambil alihpenguasaan tanah tersebut dan diserahkanke PT. Gili Trawangan
Indah (GTI) dengan pola perjanjian Kontrak Kerja Produksi dengan memberikan Hak Pengelolaan Lahan selama 70 tahun (Perjanjian Pemerintah Daerah NTB dengan PT. DGI tertuang dalam Perjanjian Pengelolaan No.1. Tahun 1993 jo.Surat Keputusan Mendagri No. 643/62-377 tanggal 4 Juni 1993. Perusahaan yang terakhir ini menunjukan sikap yang tidak bertanggung jawab sampai lebih dari 10 tahun tidak memanfaatkan tanah tersebut sesuai peruntukan dan perizinan untuk membangun perhotelan.

Diktum ke 8 SK Mendagri di dalamnya ditegaskan bahwa dalam waktu 2 tahun sejak penetapan ini. Pembangunan cottage dan sarana penunjang lainnya belum dimulai, Gubernur setelah diberikan peringatan sebanyak 3 kali maka Gubernur mencabut dan membatalkan perjanjian tersebut dan mengalihkan kepadaorang lain.

Faktor kelima, tidak jelasnya perlindungan hukum yang diberikan kepada masyarakat yang telah turun-temurun menggarap tanah tersebut. Pemerintah tidak mengakomodir keinginan luhur dari masyarakat yang telah menggarap tersebut untuk memperoleh sertifikat hak atas tanah sebagai alas hak yang sempurna. Sejatinya manakala HGU dan HPL telah gagal dilaksanakan oleh pemegang HGU dan HPL, maka prioritas utama harusnya diberikan kepada masyarakat untuk mengelola tanah tersebut dengan Pola Kerjasama Produksi, bukan diberikan kepada orang lain yang tidak berdomisili di Gili Terawangan. Hal ini mengakibatkan PT. Gili Trawangan Indah (PT. GTI) tidak mampu untuk melakukan dan mewujudkan rencananya untuk mengelola lahan tersebut karena mendapat penolakan dari masyarakat dan menerima kenyataan bahwa tanah tersebut telah dikuasai oleh masyarakat sejak tahun 1973. Keadaan ini menjadikan adanyakonflik pertanahan yang berlarut karena pen-dekatan yang dipakai oleh pengusaha adalan pendekatan kekuasaan.

Faktor keenam, bahwa semakin meningkatkan suhu konflik pertanahan adalah sikap aparat kepolisian dan aparat keamanan lainnya yang menunjukan sikap arogansi dan dipandang lebih berpihak kepada pengusaha daripada rakyat kecil. Tindakan kepolisian yang melakukan 
penahanan kepada mayarakat yang menggarap tanah HGU yang terlantar ternyata semakin mempersulit terciptanya suasana damai di Gili Terawangan. Hal itu semakin menyakitkan lagi ketika aparat keamanan (TNI) dengan dalih operasi minuman keras dan narkoba harus diterjunkan dengan kekuatan penuh di Gili Terawangan denganmendirikan tenda-tenda di lahan HGU yang ditelantarkan oleh pengusaha. Kegiatan ini dinilai sebagai gendrang perang oleh masyarakat. Penguasaan tanah pariwisata di Gili Terawangan yang dipenuhi dengan konflik saat ini adalah sebuah persoalan yang kompleks karena diabaikannya prinsip hukum yang mengatur tentang tanah terlantar secara substansi, dan faktor faktor non hukum lainnya.

\section{Penyelesaiann Konfik Terhadap Tanah Terlan- tar di Gili Trawangan}

Peraturan Pemerintah N0. 11 Tahun 2010 tentang Penertiban dan PendayagunaanTanah Terlantar didalamnya telah diamanatkan agar penertiban tanahterlantarkan dikembalikan untuk sebesar besarnya kemakmuran rakyat. Peraturan Badan Pertanahan Nasional No. 4 Tahun 2010 tentang Tata cara Penertiban Tanah Terlantar, dalam padal 1 angka 6 digariskan tentang tanah terlantar, yaitu tanah yang sudah diberikan hak oleh negara berupa Hak Milik, Hak Guna Usaha (HGU), Hak Guna Bangunan (HGB), Hak Pakai, Hak Pengelolaan yang tidak diusahakan, tidak dipergunakan atau tidak dimanfaatkan sesuai dengan keadannya atau sifatnya dan tujuan pemberian.

Tanah yang ditelantarkan itu harus didayagunakan dengan meningkatkan akses sosial ekonomi masyarakat, optimalisasi pengusahaan, penggunaan dan pemanfaatan tanah, mengurangi kemiskinan, menciptakan lapangan kerja, meningkatkan ketahanan pangan. Berdasarkan cita citadi atas maka perlu diadakan dekomposisi yang meliputi 5 komponen reformasi agraria secara filosofis. Pertama, restrukturisasi penguasaan aset tanah ke arah penciptaan struktur sosial ekonomi; kedua, politik yang berkeadilan (equity); ketiga, kesejahteraan yang berbasis keagrariaan (welfare); keempat, pemanfaatan tanah secara optima (effi- ciency); kelima, keberlanjutan (sustainability) dan penyelesaian sengketa secara harmoni.

Penjelasan Umum UUPA Bagian II angka 4 ditegaskan bahwa berhubung dengan fungsi sosialnya, maka adalah suatu hal yang sewajarnya bahwa tanah itu harus dipeihara baik baik,agar bertambah kesuburannya serta dicegah kerusakannya. Sejatinya penyelesaian konflik pertanahan dapat dilakukan secara adat melalui pranata lokal sebagamana dilaksanakan diberbagai tempat di Pula Lombok. ${ }^{11}$ Berbagai upaya yang dilakukan secara mediasi di Gili Terawangan tidak mampu menyelesaikan masalah secara tuntas. Sementara secara legitasi dengan mengajukan persoalan konflik petanahan ke pengadilan, juga tidak akan membawa hasil yang membahagiakan. ${ }^{12}$ Berdasarkan landasan yuridis dan fiosofis di atas maka seharusnya pemanfataan tanah terlantar harus memberikan kesejahteraan kepada masyarakat dan menciptakan suasana damai dan harmoni di daerah tersebut.

Berdasar uraian di atas, terlihat bahwa penyebab terjadinya konflik pertanahan di Gili Terawangan yang terdiri dari enam masalah pokok. Persoalannya apakah pemerintah daerah telah melakukan upaya penyelesaian konflik secara sistemik dan sistematis dengan memperhatian faktor penyebab konflik tersebut.

Berdasarkan hasil penelitian penulis bahwa penyelesaikan konflik tanah terlantar di Gili Trawangan Lombok lebih banyak dilakukan secara refresif dan kekuasaan serta pendekatan yang bersifat litigasi (baik secara pidana dan perdata). Secara pidana terbukti dengan dilaporkannya masyarakat masyakarat yang menggarap tanah tersebut dalam perkara pidana atas laporan PT. WAH. Akibatnya masyarakat harus mendekam di dalam tahanan karena dianggap meyerobot tanah PT. WAH yang tidak memiliki bukti yang sah atas kepemilikan tanah tersebut (Putusan Pengadilan Negeri Mataram No. 132/PID. Rin/2010/PN.Mtr tanggal 28 Desember 2010, dan Putusan PN Mataram No. 3/ Pid.Rin/2011/PN.Mtrtanggal31 Maret 2011).

Tindakan lain yang telah dilakukan pemerintah daerah dalam menertibkan konflik pada

11 Muhamad Galang Asmara, loc. cit. HIm. 3.

12 R. Fitriani, op.cit, hlm. 458 - 473. 
lokasi tanah terlantar di Gili Terawangan adalah melakukan tindakan yang cenderung represif dan dianggap berpihak kepada pengusaha (PT. WAH). Hal ini dilakukan dengan menggelar operasi "Gatarin" yang dilakukan oleh Kapolda NTB dibantu oleh aparat keamanan lainnya dengan dalih melakukan pemberantasan premanisme, narkoba dan minuman keras. Akan tetapi operasi Gatarin itu justru terkesan membela kepentingan PT.WAH yaitu dengan mendirikian tenda tenda POSKO dan melakukan intimidasi serta penggusuran kepada masyarakat yang menempati areal tanah HGB PT. WAH sehingga menimbulkan ketegangan dan suasana tidak kondusif bagi para wisatawan.

Tindakan seperti itu mendapat kecaman dari Komisi Nasional Hak Asasi Manusia (KOMNASHAM) dengan suratnya tanggal 5 Juli 2012 No. 1.411/K/PMT/VII/2012 yang ditujukan kepada Kapolda NTB. Komnas HAM dalam surat tersebut mendesak Polda NTB untuk melakukan beberapa hal. Pertama, tidak mengambil inisiatif untuk pelaksanaan putusan pengadilan karena hal tersebut merupakan kompetensi kejaksaan; kedua, menertibkan jajarannya untuk tidak menjalankan praktik apapun yang dapat dianggap sebagai intimidasi terhadap warga meskipun di tanah sengketa; ketiga, mengkaji ulang penahanan terhadap warga yang disangka melakukan pengrusakan karena menurut warga tidak ada buktiyang menguatkan.

Memperhatikan tensi konflik yang begitu tinggi antara masyarakat yang mendiami tanah yang di klaim sebagai hak milik PT. WAH dengan PT.WAH, maka penyelesaian konflik di Gili Terawangan hanya bisa dilakukan dengan beberapa pendekatan. Hasi studi di atas memberikan kejelasan bahwa penyelesaian konflik terhadap pertanahan di Gili Terawangan ternyata mengalami kegagalan jika dilakukan dengan pendekatan letigasi dan pendekatan represif (kekuasaan dan keamanan). Penyelesaian konflik di Gili Terawangan harus dilakukan secara komprehensif dan menyeluruh dengan lebih menekankan kepada aspek keadilan, kemanfaatan dan kepastian hukum. Pemerintah dan siapa saja yang hendak menjadi mediator terhadap penyelesaian suatu konflik pertanah- an, maka salah satu prinsip yang harus dijunjung tinggi bahwa penyelesaian itu harus benarbenar tuntas secara menyeluruh tanpa menyisakan masalah sekecil apapun yang kelak akan menjadi pemicu lahirnya konflik baru. ${ }^{13}$

Ada beberapa hal yang harus diperhatikan dalam penyelesaian konflik pertanahan. Pertama, tanah yang saat ini menjadi obyek sengketa dan pemicu konflik antara pengusaha dan rakyat terlebih dahulu dinyatakan sebagai tanah negara yang berada dalam status quo. Demi terwujudnya kepastian hukum atas status HGU tersebut, dalam posisi ini maka pengusaha yang telah menelantarkan tanah harus dicabut HGU dan seluruh perizinan yang melekat sehingga pengusaha yang nakal tersebut tidak menggunakan HGU sebagai tameng untuk membenarkan tindakannya secara perdata dan pidana (membuat laporan ke polisi). Pemerintah, terutama aparat kepolisian harus menghentikan penyelidikan, penyidikan dan penangkapan terhadap masyarakat Gili Terawangan yang dianggap menggarap tanah milik pengusaha. Oleh karena status tanah tersebut secara perdata masih dalam keadaan terlantar dan bukan hak milik mutlak pengusaha. Menahan dan memenjarakan masyarakat atas dasar laporan pengusaha (yang menelantarkan tanah) dapat mencederai rasa keadilan dan mempersulit penyelesaian secara tuntas.

Kedua, Pemerintah Daerah, Badan Pertanahan, aparat kepolisian harus duduk dalam satu forum untuk mendengar keinginan rakyat yang telah berpuluh tahun menggarap tanah tersebut. Melalui forum mediasi ini Pemerintah dan Badan Pertanahan harus memberikan solusi yang jelas dan tegas tentang status tanah tersebut, dan bila perlu dengan mengacu prinsip keadilan, maka pemerintah harus memberikan jaminan dengan memberikan hak kepada rakyat (penggarap) suatu bukti hak milik (sertifikat) sesuai dengan kebutuhannya, karena keinginan penggarap cukup sederhana yaitu diberikan lahan yang cukup untuk tempat berusaha

13 Akh Munif, loc.cit, hlm. 4 
dengan jaminan sertifikat hak milik. Pola seperti ini pernah dilakukan. ${ }^{14}$

Ketiga, jika tanah Gili Terawangan yang telah ditelantarkan (kembai menjadi milik negara) maka Pemerintah harus mempertimbangkan lebih jauh untuk tidak memberikan kembali HGU kepada badan usaha (PT) yang selama ini menjadi bagian dalam konflik pertanahan karena mengembalikan PT WAH yang selama ini dianggap sebagai musuh dan mencederai rasa keadilan masyarakatakan merobek kembali luka lama yang dirasakan masyarakat yang telah dipenjarakan oleh tindakan PT. WAH.

Keempat, sesuai keinginan masyarakat dan dengan mengacu pada padal 42 ayat (2) UU No.1 Tahun 2004 maka terhadap tanah Gili Terawangan diharapkan dapat dikelola secara lebih produktif melalui pola kerjasama Pemerintah Daerah dengan Pihak Swasta. Pemilihan Partner kerjasama itu haruslah memperhatikan ketentuan yang diatur dalam PP No. 50 Tahun 2007 tentang Kerjasama Pemerintah dengan Pihak Ketiga jo Perpres No.13 Tahun 2010 dan memperhatikan nilai nilai yang ada di tengah masyarakat. Pemerintah harus membuka peluang kepada semua perusahaan/Badan Hukum untuk mengajukan permohonan kembali dengan proposal yang kompetitif melalu pola kerjasama antara Pemereintah dengan Pihak Swasta. Pemerintah melalui team independen harus menilai perusahaan mana yang layak dan dianggap mampu mengembangkan tanah Gili Trawangan sebagai resort pariwisata sehingga tidak terulang kasus PT WAH yang dianggap kurang memiliki kemampuan dari segi ke-uangan dan teknis. Semua proses tersebut harus dilakukan secara jujur, transparan dan objektif mengikuti mekanisme hukum yang telah diuraikan di atas. Upaya sosialisasi dan publikasi atas rencana penataan ulang harus benar-benar dilakukan secara luas agar partisipasi masyarakat

14 Reni Rosmitasari, Rina Martini, Puji Astuti, "Peran Pemerintah Daerah Dalam Penyelesaian Sengketa Tanah di Lahan PASIFIC MALL Kota Tegal", Journal of Politic and Government Studies, Vol. 2 No. 4 Tahun 2013, Semarang: UNDIP, Halaman 12. mendukung upaya penyelesaian konflik tersebut. ${ }^{15}$

Kelima, bahwa pemerintah, terutama aparat kepolisian harus menghentikan penyelidikan, penyidikan dan penangkapan terhadap masyarakat Gili Terawangan yang dianggap menggarap tanah milik pengusah karena status tanah tersebut secara perdata masih dalam keadaan terlantar dan bukan hak milik mutlak pengusaha. Menahan dan memenjarakan masyarakat atas dasar laporan pengusaha (yang menelantarkan tanah) dapat mencederai rasa keadilan dan mempersulit penyelesaian secara tuntas.

\section{Penutup}

Simpulan

Konflik pertanahan yang berangsung lama di Gili Terawangan merupakan persoalan yang sangat sistemik yang diakibatkan oleh adanya kebijakan yang salah dibidang pertanahan (khususnya di kawasan wisata), adanya sikap yang tidak tegas dari Pihak Pemerintah Daerah dan Badan Pertanahan dalam penegakan peraturan hukum pertanahan yang diatur dalam Peraturan Pemerintah No. 11 Tahun 2010 tentang Penertiban dan Pendayagunaan Tanah Terlantar jo Peraturan Badan Pertanahan Nasional No. 4 Tahun 2010 tentang Tatacara Penertiban Tanah Terlantar, adanya kecemburuan sosial dari masyarakat asli Gili terawangan sebagai penggarap, kurang bertanggung jawabnya pihak pengusaha (yang memperoleh Hak Guna Usaha), tidak adanya perindungan hukum bagi Penduduk Asli Gili Terawangan, sikap arogansi dan represif aparat penegak hukum dalam menghadapi masyarakat.

Penyelesaian konflik terhadap tanah yang ditelantarkan dan telah dikuasai oleh masyarakat hanya dapat dilakukan secara non litigasi dengan memperhatikan rasa keadilan, kemanfaatan dan jaminan kepastian hukum bagi hak hak masyarakat. Pemerintah dalam hal ini adalah Badan Pertanahan memberikan prioritas kepada masyarakat lokal yang mendiami tanah ta-

15 Agung Widodo, "Urgensitas Penyuluhan Hukum Agraraia Pada Masyakat Rawan KonflikPertanahan", Jurnal Yustitia No.75 Th 2008, hlm. 3 
nah tersebut untuk memperoleh hak milik atau HGU secara adil dan seimbang yang luas-nya disesuaikan dengan kemampuan modal dan bentuk usaha yang dijalankan oleh masyarakat. Pemerintah harus melakukan seleksi yang ketat dalam memberikan izin dan HGU terhadap calon pengusaha yang ingin kembali berinvestasi di Gili Trawangan, diutamakan perusahaan yang tidak memiliki latar belakang konflik dengan masyarakat. Pengusaha yang ingin berinvestasi sebaiknya dilakukan dengan pola kerjasama dengan membuka peluang semua pihak secara kompetetif dan transparan. Semua Proposal Badan Hukum tersebut haruslah dinilai secara objektif oleh team independen agar diperoleh $\mathrm{Ba}$ dan Usaha yang benar benar memiliki kemampuan keuangan, sumberdaya dan tehnis untuk mengembangkan kawasan Gili Terawangan. Seluruh mekanisme pemilihan mitra kerjasama itu harus mengacu pada PP No.50 Tahun 2007 jo. Perpres No. 13 Tahun 2010.

\section{Daftar Pustaka}

Fitriani, R. "Penyelesaian Sengketa Lahan Hutan Melalui Proses Mediasi di Kabupaten Siak". Jurnal Unsri. No. 3 Vol. 14 Juli 2007;

Galang, Asmara, Muhamad dkk. "Penyelesaian Konflik Pertanahan Berbasis Nilai-Nilai Kearifan Lokal di Nusa Tenggara Barat". Jurnal Mimbar Hukum. Vol. 22 No. 1 2010. Yogyakarta: FH UGM;

Hastiti, Dara Hapsari. "Penyelesaian Konflik Pertanahan di Kabupaten Nunukan di Kalimantan Timur antara Masyarakat dengan Perusahaan Perkebunan dihubungkan dengan Peraturan Pemerintah No 11 Tahun 2010 tentang Penerbitan dan Pendayagunaan Tanah Terlantar". Jurnal FH UNPAD. Vol. 17 Oktober 2013;

Ibrahim, Anis. "Penyelesaian Sengketa Tanah Kawasan Hutan Negara di Kabupaten Lumajang". Jurnal Hukum Argumentum. Vol. 3 No. 2 Januari-Juni 2004;

Munif, Akh. "Perlindungan Hukum Terhadap Hak-Hak Rakyat Atas Tanah Dalam Pembangunan (Kajian Atas Perpres No. 65 Tahun 2006)". Jurnal Justisia. Vol. 11 No. 1 Mei 2011. Madura: FH Universitas Madura;
Nurjannah, Siti. “Kajian Hukum Sengketa Pertanahan dan Penyelesaiannya (Putusan Kasasi MA No. 2863/K/ Pdt/1999 Dalam Perkara Perdata Tingkat Kasasi Antara PT. Portanigra Melawan H. Juhri M. Yatim Tugono dan Yahya bin H. Geni". Jurnal Supremasi Hukum. Vol. 3 No.1 tahun 2013. FH Universitas Sahid Jaya;

Rosmitasari, Reni. dkk. "Peran Pemerintah Daerah Dalam Penyelesaian Sengketa Tanah di Lahan PASIFIC MALL Kota Tegal". Journal of Politic and Government Studies. Vol 2 No 4 Tahun 2013. Semarang: UNDIP;

Shidarta. “Peragaan Pola Penalaran Hukum Dalam Kajian Putusan Kasus Tanah Adat Kajian Putusan Nomor 22/PDT.G/2004/ PN.AB”.Jurnal Yudisial Pergulatan Nalar \& Nurani. Vol. III No. 03 Desember/2010;

Widodo, Agung. "Urgensitas Penyuluhan Hukum Agraraia Pada Masyakat Rawan Konflik Pertanahan". Jurnal Yustitia. No.75 Tahun 2008;

"Urgensitas Penyuluhan Hukum Agraria. Pada Masyarakat Rawan Konflik Pertanahan". Jurnal Yustitia. No.75 Th 2008;

Wiradi, Gunawan. “Jangan Perlakukan Tanah sebagai Barang komoditi”. Jurnal Analisa Sosial. Edisi 3 Juli 1996. Bandung: Yayasan Akatiga. 
